\title{
The voices of the tale: the storyteller in early Byzantine collective biographies, miracle collections, and collections of edifying tales
}

Stavroula Constantinou

University of Cyprus

konstans@ucy.ac.cy

\author{
Andria Andreou \\ University of Cyprus \\ andreou.andria@ucy.ac.cy
}

This article is a first attempt to approach the figure of the storyteller in three types of early Byzantine tale collections (fourth-seventh centuries): collective biography, miracle collection, and collection of edifying tales. Our approach draws significantly on Walter Benjamin's discussion of the storyteller and Monica Fludernik's work on conversational storytelling. Our analysis has a twofold purpose: first, to revise the impression that the storyteller is a canonical force that possesses the same characteristics in every single tale; second, to suggest that the storyteller is an inherent feature of short hagiographical narratives.

Keywords: storyteller; hagiographical tale collections; biography; miracle; beneficial tale

The research for this article was co-funded by the European Regional Development Fund and the Republic of Cyprus through the Foundation of Research and Innovation (Project: Post-Doc/0718/0021). Some of the ideas that inform the article's arguments were developed in the framework of the project 'Network for Medieval Arts and Rituals' (NetMAR), which received funding from the European Union's Horizon 2020 research and innovation programme under grant agreement No. 951875. The opinions expressed in this document reflect only the authors' view and in no way reflect the European Commission's opinions. The European Commission is not responsible for any use that may be made of the information it contains.

(C) The Author(s), 2021. Published by Cambridge University Press on behalf of Centre for Byzantine, Ottoman and Modern Greek Studies, University of Birmingham. This is an Open Access article, distributed under the terms of the Creative Commons Attribution-NonCommercial-NoDerivatives licence (https://creativecommons.org/licenses/bync-nd/4.0/), which permits non-commercial re-use, distribution, and reproduction in any medium, provided the original work is unaltered and is properly cited. The written permission of Cambridge University Press must be obtained for commercial re-use or in order to create a derivative work.

DOI: $10.1017 /$ byz.2021.31 
Let us start by citing the prologues of three early Byzantine collections of hagiographical tales: a collective biography (History of the Monks in Egypt, fourth century; hereafter $H M E$ ), a miracle collection (Miracles of Thekla, fifth century; hereafter MT), and a collection of edifying tales (Lausiac History, 420; hereafter LH):

For He brought us to Egypt and showed us great and wonderful things which are worthy of being remembered and recorded. ... The pious community ... has asked me repeatedly to write them an account of the practices of the Egyptian monks which I have witnessed. ${ }^{1}$ (HME)

I have assembled her miracles scattered here and there and published them in this small collection. ${ }^{2}(M T)$

I wrote down some of the things I saw, and also some accounts I heard from the holy fathers. ${ }^{3}(L H)$

As attested in these authorial comments, the tales were originally transmitted orally. At some point a pious man, such as a monk from a Jerusalemite monastery on the Mount of Olives, a priest serving Thekla's shrine in Seleukeia, and the monk Palladios and later bishop of Helenopolis in Bithynia, ${ }^{4}$ committed them to writing after drawing on his own experiences and making a selection from the tales he managed to assemble during his encounters with other storytellers, his researches, and his travels, producing thus an anthology that enabled the survival of the stories in different versions and languages over the centuries. ${ }^{5}$ The three writers in question, as with most hagiographers producing tale collections, assume the storyteller's role as defined by Walter Benjamin in his well known essay 'Der Erzähler: Betrachtungen zum Werk Nikolai Lesskows' (1936). ${ }^{6}$

The storyteller, Benjamin tells us, is the individual who has the ability to tell and re-tell stories that are transmitted from mouth to mouth and from generation to generation over the centuries. These stories are either collected through travelling to

1 Tr. N. Russell, The Lives of the Desert Fathers: the Historia Monachorum in Aegypto (Oxford 1981), 49; ed. A.-J. Festugière, Historia monachorum in Aegypto (Brussels, 1971).

2 Trans. S. Fitzgerald Johnson, 'Miracles of Saint Thekla', in A.-M. Talbot and S. Fitzgerald Johnson (tr.), Miracle Tales from Byzantium (Washington, DC 2012), 3; ed. in G. Dagron, Vie et miracles de sainte Thècle: texte grec, traduction et commentaire (Brussels 1978).

3 Trans. R. T. Meyer, Palladios: The Lausiac History (Mahwah, NY 1964), 18-19; ed. in C. Butler, The Lausiac History of Palladius, vol. 2 (Cambridge 1898), 1-169.

4 For the author of the HME, see B. Ward, 'Introduction', in Russell, Lives of the Desert Fathers, 1-46 (7); as for the hagiographer of Thekla's miracle anthology, see G. Dagron, 'L'auteur des “Actes” et des "Miracles" de Sainte Thècle', Analecta Bollandiana 92.1/2 (1974) 5-11; Dagron, Vie et miracles de sainte Thècle, 13-19. 5 The $L H$, for example, one of the most popular early Byzantine hagiographical tale collections, (Butler, The Lausiac History of Palladius, Vol. 2, iii-iv). There are different versions of the Lausiac History in Latin and Oriental languages (Butler, The Lausiac History of Palladius, Vol. 1, 6-172).

6 W. Benjamin, 'The storyteller: reflections on the works of Nikolai Leskov', in W. Benjamin, Illuminations: essays and reflections, ed. H. Arendt, tr. H. Zohn (New York 1969), 83-109. 
distant places or acquired through access to local lore. 'The storyteller', Benjamin goes on, 'takes what he tells from experience - his own or that reported by others. And he in turn makes it the experience of those who are listening to his tale.... Storytelling is always the art of repeating stories. ${ }^{7}$ For this reason, 'storytellers tend to begin their story with a presentation of the circumstances in which they themselves have learned what is to follow, unless they simply pass it off as their own experience'. ${ }^{8}$ Such a tendency can be detected in our hagiographical storytellers. John Moschos, for instance, introduces the third tale of his Spiritual Meadow (seventh century; hereafter SM) thus: 'At the lavra of our holy father Sabas we met Athanasios. The elder told us this tale."

For Benjamin, storytelling is craftsmanship. The storyteller works with his material and fashions it in a solid, useful, and distinctive way. In so doing, the storyteller becomes a teacher and a sage offering counsel to his audiences, taking the form of a moral message, a piece of practical advice, a proverb, or a maxim. In short, the storyteller does not just communicate a story, but allows his listeners to integrate the story into their own experience, which they are, in turn, invited to share with others by becoming storytellers, too. Storytelling emerges as a gift, an act of generosity which the receiver should reciprocate sharing his own experience in the form of another story or in circulating the same story in his own distinctive voice. In Benjamin's closing words, 'the storyteller is the figure in which the righteous man encounters himself' ${ }^{10}$ This 'righteous man' might be the hero of the story, the storyteller himself who identifies with his hero, and the listener who associates with both hero and storyteller.

It is precisely this sense of the virtuous forces that unite hero, storyteller, and listener which Byzantine hagiographical storytellers espouse. As the anonymous storyteller of the $H M E$ emphatically points out, 'I have therefore trusted in their [the monks of his monastery in Jerusalem] prayers to apply myself to the composition of this narrative so that I too should derive some profit from the edifying lives of these monks [in Egypt] through the imitation of their way of life' (HME, prol. 17-20). ${ }^{11}$ The hagiographerstoryteller undertakes to commit to writing the stories he has collected through his journey to the Egyptian desert and to describe his experiences with the desert Fathers with the intention of offering a gift to both himself and his fellow monastics, and by extension to anyone who would read or listen to his stories. His own storytelling that brings to life that of the desert Fathers aims at inspiring himself and his fellow monastics to somehow replicate the Fathers' conduct and storytelling tradition. It is in fact our storyteller's generosity and very purpose that fill the HME with moral insistence and believability.

7 Benjamin, 'Storyteller', 87, 91.

8 Benjamin, 'Storyteller', 92.

9 Transl. (with minor changes) J. Wortley, John Moschos, The Spiritual Meadow (Pratum Spirituale) (Kalamazoo 1992), 5; ed. in Patrologia Graeca 87/3: 2852-3112, at 2853.

10 Benjamin, 'Storyteller', 109.

11 Russell, Lives of the Desert Fathers, 49. 
Drawing on Benjamin's concept of the storyteller and Monika Fludernik's work on conversational storytelling, as exemplified in her book Towards a 'Natural' Narratology (1996), ${ }^{12}$ the present article approaches the profiles, forms, and functions of the storyteller as detected in three categories of early Byzantine hagiographical tale collections: collective biographies, miracle collections, and collections of edifying tales. ${ }^{13}$ The present investigation embraces Fludernik's axiom that storytelling constitutes an archetype of all narration in its function as a form of narrative. Even though Fludernik, like most narratologists, ${ }^{14}$ focuses on longer narrative structures as these have developed from oral storytelling to the realist novel and beyond, her fundamental association of the storyteller with orality proves useful in our attempt to investigate the voice(s) of Byzantine tales emerging from a strong oral tradition, that of early monasticism, and having a didactic, moral, but also entertaining character.

It has to be pointed out, however, that both Benjamin and Fludernik treat the figure of the storyteller as a canonical force that possesses the same characteristics in every single tale. The present study, in contrast, argues that this is not always the case in the examined tales. In an effort to unearth the mechanisms that underpin the function of the storyteller, we argue that in Byzantine tales there are at least two modes or manners under which the storyteller function operates: single-voice storytelling and chain storytelling. These are materialized in three types of storytellers: the single omnipresent storyteller, the chain storyteller, and the combined storyteller.

The prime distinction between the two modes of storytelling detected in our corpus concerns the number of voices involved in tale transmission. In this respect, single-voice storytelling is defined as the mode performed by an omnipresent storyteller, identified with the author of the collection and responsible for transmitting all its tales. Chain storytelling, on the other hand, refers to the mode in which a particular tale is transmitted through a sequence of storytellers. This type of storytelling is enacted when a storyteller confides a tale to someone who then re-tells it to another individual, who, in turn, transmits it to a third potential storyteller, and so on, reflecting the innumerable times that a tale is orally transmitted through the centuries. On the level of the tale collection, however, the final link in the chain is the voice of the storyteller-hagiographer.

12 M. Fludernik, Towards a 'Natural' Narratology (London 1996).

13 For an introduction to each of these three hagiographical collections, see P. Cox Miller, 'Strategies of representation in collective biography: constructing the subject as holy', in T. Hägg and P. Rousseau (eds) Greek Biography and Panegyric in Late Antiquity (Berkeley 2000) 209-54; S. Efthymiadis, 'Collections of miracles (Fifth-Fifteenth Centuries)', in S. Efthymiadis (ed.), The Ashgate Research Companion to Byzantine Hagiography, vol. 2: Genres and Contexts (Farnham 2014), 103-42; A. Binggeli, 'Collections of edifying stories', in Efthymiadis, The Ashgate Research Companion to Byzantine Hagiography, vol. 2, 143-59.

14 S. Copland, 'To be continued: the story of the short story theory and other narrative theory', Narrative 22.1, 132-49. 
In the collections we examine, the aforementioned modes of storytelling appear either separately or together and seem to be associated with the subgenre to which each tale belongs. Single-voice storytelling is dominant in collections of miracle tales associated with a particular shrine and devoted to a saint's miraculous deeds. Chain storytelling, by contrast, rarely appears on its own but usually in the form of what we call 'combined storytelling, that is storytelling at times heard through a single voice and at other times transmitted through a chain of voices. Combined storytelling is central in collective biographies and collections of edifying tales which include stories concerning different individuals dispersed in time and space, a reality that necessitates a collective tale exchange.

Combined storytelling takes the following form: the omnipresent storyteller, who is also the author of the collection, appears from the outset, in the text's prologue, and undertakes to tell a considerable number of the collection's tales. The remaining tales of the collection are presented as reaching the storyteller-author through a chain of storytellers. There is, however, a storytelling differentiation between collective biographies and collections of edifying tales. In the first, the omnipresent storyteller is overshadowed to a great degree by the existence of the storyteller chain; while in the latter, the omnipresent storyteller and the chain of storytellers are represented in equal terms.

Besides their implications for genre, storytelling modes and the type of storyteller emerging from each collection category have structural implications for texts. Such a structural implication concerns the organization of the tales within a collection. The arrangement of the stories in miracle collections is often determined by the miracle's type (e.g. healing miracle) and/or the beneficiary's character determined by age, gender, status, and physical condition. The organization of stories in collective biographies and collections of edifying tales, on the other hand, is mostly made according to the hagiographer's movement in space as he meets different ascetics. These ascetics may be the protagonists of the stories, in which case their name and/or deed(s) appear in the tale title, or they may be storytellers sharing one or more stories with the hagiographer.

Of course, the interpretative guidelines suggested here are not meant to be applied as holistic frames. In other words, this study does not wish to imply, for instance, that combined storytelling never occurs in miracle collections. Furthermore, it would be unreasonable to suggest that the storytelling type of a specific collection does not also acquire unique features which are determined by authorial creativity. However, as our analysis demonstrates, these proposed interpretative guidelines can be a valuable theoretical tool in this first attempt to understand the complex figure of the storyteller in early Byzantine collections of hagiographical tales.

\section{Single-voice storytelling}

In a number of early Byzantine miracle collections, the figure of the storyteller is quite robust. He is mostly a learned man from the ecclesiastical hierarchy who undertakes to re-tell the tales he has heard and to present his own personal experiences which he shapes as independent stories. Through his all-pervasive voice, he seems to exemplify 
Benjamin's and Fludernik's view of the storyteller as a single and unchanged force predominant throughout the text: the miracles' storyteller becomes atemporal as Benjamin would have it. At the same time, his tales become ahistorical, since the events they relate could have occurred at any time from the saint's death to the time of any given audience. Despite their ahistoricity, however, the tales are permeated by an essentially unchanged locality, the saint's shrine. ${ }^{15}$

The single storyteller is present in all parts of his collection: its prologue, epilogue, and every single tale in an attempt to gain the audience's trust which has to be continuously nourished in order to remain strong until the end of the text and thereafter. To achieve this crucial purpose, the storyteller does not just tell tales: he reveals his own experiences, feelings, and thoughts, and assumes the role of an authoritative commentator and teacher. Mostly the storyteller shares his experiences and internal world in the tales involving episodes he himself witnesses or events in which he has a central role. Such semi- or fully autobiographical tales render the storyteller even more trustworthy and bring him closer to his audience. A case in point is an autobiographical tale from Thekla's miracles:

I blush to tell of the miracle concerning myself ... But I will tell it nevertheless ... 'Anthrax' is the name given by physicians to a certain malady which feels like a hotly burning inflammation ... I contracted this in one of my fingers on one hand ... I was greatly afraid, as were the doctors ... They decided next to ... amputate the finger ... This is the vision which happened to me. But when daylight appeared and began to shine, I found I had been delivered from that fierce pain and suffering, so that I was even smiling and gladdened at the blessed vision. ${ }^{16}$ (MT, ch. $\left.12, \mathbb{\$} \$ 1-3\right)$

Before setting out to tell the miracle tale, the storyteller's autobiographical voice highlights his embarrassment for having to talk about himself. In so doing, the storyteller attempts to create a self-portrait of a modest man whose aim is to glorify Thekla, even if he has to talk about the special treatment that he receives from her as one of her truest devotees. In fact, he does not fail to bring to the fore in a number of tales his particular relationship with the martyr in a further strategy to establish his authority as a storyteller, or, in Benjamin's terms, a sage. In the autobiographical miracle tale cited above, the storyteller lays himself open. He talks about his personal experience of a dangerous and painful disease which threatens his bodily integrity and

15 For the authors, audiences, and localities of Byzantine miracle collections, see S. Constantinou, 'Horizons of clerical authors and audiences: towards a sociology of the miracle story collection', Proceedings of the 23rd International Congress of Byzantine Studies, Belgrade, 22-27 August 2016, Round Tables (Belgrade 2016), 86-90, http://www.byzinst-sasa.rs/srp/uploaded/PDF\%20izdanja/round\% 20tables.pdf; the characteristics of the Byzantine miracle collection from the fourth to the fourteenth centuries are investigated in S. Constantinou, Byzantine Thaumaturgic Narratives: the art of miracle story collection (forthcoming).

16 Fitzgerald Johnson, 'Miracles of Saint Thekla', 47-49. 
shares his anxieties and fears. He thus reveals part of his humanity with which his listeners may identify.

The single omnipresent storyteller does not only disclose his own experiences and feelings but tells his audience how to experience his tales. A case in point is the following passage from bishop John's Miracle Collection of Demetrios (seventh century; hereafter $M D):^{17}$

Listen to what has happened, listen; yet do not raise your spirit only to the point of admiration and praise towards the martyr, but by completely observing the willingness and love of the bearer of the palm (athlophoros), embrace this with all your soul and strength and, so that you emerge as careful listeners and, through this, as genuine friends of his benevolence. ${ }^{18}(M D$, ch. $10, \$ 85)$

As he is about to narrate a turning point in the story, the storyteller interjects for his listeners clear instructions regarding the way they should emotionally process the narration that is about to follow. John exhorts his audience to listen carefully because it is only through attentive listening that they will be able to express their admiration for the martyr's deeds and make the story as part of their own emotional and mental world and thus allow them to reach a state of intimate friendship with the martyr.

In addition to providing an avenue into his emotional world, the single omnipresent storyteller also seeks to create a relationship with his audience by assuming a commentator's role, expresses his opinion about certain incidents and the persons involved. For example, in a tale included in MT, which concerns the healing of a child's injured eyes, the storyteller interrupts the course of events exclaiming:

Which part of our body is as beautiful as this? Which is so necessary and useful, as radiant eyes which see as much as they illumine, and which receive and impart an equal amount of light in all activities? Just as in this firmament, if one should remove the second-ranked of the luminous bodies [the moon], one would significantly diminish the beauty of heaven itself, but also of the earth. ${ }^{19}$ (MT, ch. $24, \mathbb{} 2)$

The questions addressed to the audience are not simply meant to add emphasis to the importance of the martyr's miraculous deeds, but also to remind the audience of the storyteller's significant roles as a transmitter and exegete of the saint's supernatural actions. A similar effect is achieved when the storyteller postpones the telling of the tale to offer explanations about phenomena and objects that might not be clear or known to his audience. This is, for instance, a very common practice of bishop John, who makes extended interjections to explain how, for example, a siege engine is constructed and used by the enemies of Thessaloniki, the city of the martyr Demetrios.

17 Ed. in P. Lemerle, Les plus anciens receuils des miracles du saint Démétrius, 1 (Paris 1979), 50-241.

18 Unless otherwise indicated, translations are our own.

19 Fitzgerald Johnson, 'Miracles of Saint Thekla', 96, 98. 
As a teacher, the omnipresent storyteller offers counsel. In the $M D$, for instance, when the storyteller is about to tell a miracle of punishment, he turns to his audience to say the following:

We will lay out for your pious hearing a punishment ... which the athlophoros unleashed upon a certain man ... who sinned as if he were a child. And let this narration act as an incitement and advice so that you do not scorn the holy by resting on the saints' God-inspired forbearance; instead, you should be in a state of constant vigilance ... first over your own hearts, but also over every blasphemous or unwise word that you may utter. $(M D$, ch. $11, \mathbb{\$} 95)$

The storyteller prompts his audience not to take advantage of the saints' benevolence, suggesting that what is to follow should be received as a lesson, as a possibility that could be avoided depending on each listener's behaviour. This feature once again coincides with Benjamin's elaboration of the storyteller acting as a sage who offers guidance and advice to his listeners. In the same way, a miracle of healing or salvation is brought forth by the storyteller in the form of aspiration - as an event likely to happen to one in need, given that the recipient has mastered certain personality traits, such as faith, piousness, and patience, that increase the likeliness of a miracle to occur. Thus, the storyteller teaches his audiences what it means to be pious and impious. The first provokes the saint's benevolence, the latter his punishment.

As our analysis has demonstrated, the omnipresent storyteller emerges as an authoritarian voice which is linked to a male persona dominantly established within the text. He can appear at any time to offer comment or clarification, to counsel, to reveal his interior world, to direct and guide his audience, and to ensure that his tales become his listeners' experience.

\section{Chain storytelling}

Combined storytelling involves features of both the single-voice and the chain mode. As a result, texts in which combined storytelling is prominent, demonstrate similarities, but also significant differences as regards the profile and functions of the voice-carrier(s). In general, collective biographies place more emphasis on a chain of storytellers rather than on an omnipresent storyteller. Chain storytellers too are pious men of equal spiritual status one with another, or enjoy a disciple-teacher relationship. Yet their personalities are quite elusive. In the first tale of the $H M E$, for example, the first storyteller of the text's first chain, John of Lykopolis, is introduced as follows:

In the territory of Lyko in the Thebaid we visited the great and blessed John, a truly holy and virtuous man. From what he did it was obvious to everyone that he possessed the gift of clairvoyance. ${ }^{20}$ (HME, ch. 1, 1-4) 
All the information concerning John as a storyteller is given in no more than two printed lines, and it concerns the degree of his holiness through which the authenticity and divinity of his tale are confirmed. The same practice is followed also for the other storytellers forming the text's various chains.

A similar phenomenon can be observed also in the $L H$. At some point, a certain man named Didymos is introduced into the narrative, and he undertakes to tell his own story and that of a woman named Alexandra $(L H, c h .4, \mathbb{S} 1)$. The only actual information the audience is offered about Didymos is that he is a blind uneducated author, who died at the age of 85 . Remarkably, these are some of the most informative references to a storyteller in the $L H$, since other chain storyteller profiles tend to be even vaguer. ${ }^{21}$ In this respect, in contrast to an omnipresent storyteller, such as that of $M T$, a storyteller in a chain provides no tangible sense of his personality. His speaking voice is quite remote. Sometimes it becomes so distant that it gives the impression of a bodiless divine voice.

Chain storytellers are always on the move. A storyteller might even travel afar to find other storytellers who could be worthy transmitters of his tale(s), as well as storytellers prepared to share their own tales with him. For example, Palladios, the main storyteller of the $L H$, tells us how he came to visit the monks of Nitria. He was prepared to traverse deserts, sail lakes, and climb mountains in order to secure tales worthy of transmission and to find storytellers willing to share them with him ( $\mathrm{LH}$, ch. $7, \mathbb{\$} \$ 1-2)$. Yet in this case and in other collections with combined storytelling, the recipient is not offered any detailed information about the chain storyteller, and the storyteller is certainly not at pains to form a relationship with his audience. One is thus left to wonder what Benjamin's image of the sage is premised on. This impression arises from the succession of so many holy fathers and virtuous disciples who assume the storyteller's role. Put differently, since every father follows another in swift succession, and since each of them is equally holy or even holier than his predecessor, the authoritative function of these storytellers is closely linked to their holy profile, and thus the tales they tell emerge as valid lessons and as 'beneficial for the soul'.

Perhaps the most telling differentiation between the pure single-storytelling mode and that of combined storytelling with a focus on the chain, is the way in which Benjamin's view of the storyteller as providing his audience with an atemporal experience is manifested. While, as already indicated, the atemporal experience of the miracle tale is associated with the likeliness of the miracle to occur at any time, the atemporal experience in chain storytelling is provided through the blending of different storytellers' voices; at times, it is difficult to discern who is speaking and when the tale takes place. Such an example is once again provided in the HME. When our main storyteller along with his group of monks pay a visit to Kopres, the latter, after following the standard ritual presented in the text, that is the washing of the visitors'

21 There is, for example, no information for the storyteller Arisios, who is mentioned for the first time in ch. 7, $\$ 6$ and who narrates the story of Amoun in the next chapter (ch. 8). 
feet, sets out to tell tales of other pious fathers. However, before allowing Kopres to assume the storyteller's role, the text's first storyteller and author undertakes to introduce Kopres:

He, without the slightest thought of pride, gave us an account of his own life and that of his great predecessors, who had become much better men than he, and whose manner of life he himself imitated. 'There is nothing wonderful about my achievements, my children', he said, 'when they are compared with the rule of life that our fathers followed'.

\section{$<$ On Patermuthios $>$}

For example, there was a father who lived before us called Patermuthios. ${ }^{22}$ (HME, ch. 10, 11-19)

A series of questions arises here: Who tells the tale of Petermuthios? To whom does this voice belong? Is it the first storyteller's voice or that of Kopres? It is after the telling of the story of Patermuthios' trip to Paradise from where he takes a miraculous fig that one is allowed to conclude with certainty that the storyteller is Kopres (HME, ch. 10, 128-52), since it is explicitly stated that he is the one who actually sees the paradisiacal fig brought by Patermuthios. Immediately after this statement comes the following sentence: 'the priest Kopres was telling us this tale' (HME, ch. 10, 141), ${ }^{23}$ which resolves any uncertainty concerning the storyteller's identity.

Through the blending of the two voices, there is also a blending of two different time levels: the time that Kopres hears the story from Patermuthios himself and the time that Kopres tells the tale to the first storyteller and his group. This blending of time levels acquires importance a few lines later, as Kopres continues his narration but is interrupted by a member of his audience who falls asleep (HME, ch. 10, 159-60). ${ }^{24}$ When the man who fell asleep wakes up, he narrates a dream in which Kopres appears holding a golden book and reproaching him for doubting the truth of his narration. This narration of the man who dozed off is offered through the voice of the first storyteller, the member of the group of monks who visit Kopres. While thus Kopres talks, we suddenly switch to our first storyteller, who informs us about what another brother tells concerning his own dream experience. Hence, within the man's dream Kopres still talks (he is still the storyteller), while out of the dream we have switched to our first storyteller who transmits the dream's content.

To complicate things further, following this incident Kopres takes on the role of the storyteller again (a further switch) and goes on to narrate his own story (HME, ch. 10, 177-88). In so doing, he returns to the time of the monks' visit that initiates this

22 Russell, Lives of the Desert Fathers, 82; emphasis added.

23 Russel, Lives of the Desert Fathers, 85.

24 Russel, Lives of the Desert Fathers, 85. 
internal chain of storytelling. To add another dimension, after Kopres finishes his story, and without any indication of who is the speaker, there is a switch back to the third person. A voice now undertakes to tell the tales of, first, abba Sourous, within which at some point the voice of abba Anouf is heard speaking (HME, ch. 11, 1-41); and, secondly, of abba Ellis (HME, ch. 12, 1-87). The most logical inference of what happens in this case, given the absence of any narrative frame and indication, would be to suppose that the tale has reverted to the main storyteller. Nevertheless, at the end of the twelfth chapter (that is, two chapters after this undefined voice begins to speak) we suddenly realize that the storyteller is still Kopres ('When Father Kopres had finished telling us these amazing stories'; HME, ch. 12, 88-9). ${ }^{25}$

There are many other instances in the HME in which such a blending of voices and time levels take place. In some cases, the structure becomes even more composite through the insertion of storytelling interjections in the form of questions. The agent of enunciation is unknown or unclear and is accompanied by the total exclusion of speaking frames. The persistence of such phenomena in many tales included in collective biographies and collections of beneficial tales supports the hypothesis that this is an intentional storytelling technique that is part of the works' organizational structures. In fact, this hypothesis is strengthened when one turns to the combined storytelling in which the omnipresent storyteller and the storyteller chain are represented on equal terms.

\section{Combined storytelling: the omnipresent storyteller and the chain}

The collection of edifying tales constitutes the par excellence text of combined storytelling. The three early collections falling into this category that are examined here, Daniel of Sketis' Narrations (6th century; hereafter DN), ${ }^{26}$ Moschos' SM, and Anastasios of Sinai's Narrations ( 7 th century; hereafter $A N),{ }^{27}$ feature an omnipresent storyteller who appears in almost every tale alongside the chain. The profile of the single omnipresent storyteller in these collections is that of a pious and learned monk whose personality, however, never becomes as open and intimate as that of the omnipresent storyteller in miracle collections, despite the fact that these storytellers, too, act as characters and protagonists of certain tales. In the $A N$, for example, we learn little about the omnipresent storyteller's profile beyond the fact that he is a monk $(A N$, ch. 8,13$)$ and that he has dwelt for a time on the Mount of Olives $(A N$, ch. 3).

Compared to Daniel and Moschos, however, Anastasios does behave in ways that bring him closer to the miracle collections' omnipresent storyteller: he makes sharp

25 Russel, Lives of the Desert Fathers, 92.

26 Ed. and trans. in B. Dahlman, Saint Daniel of Sketis: a group of hagiographic texts edited with introduction, translation, and commentary (Uppsala 2007).

27 Ed. in F. Nau, 'Le texte grec des récits utiles à l'âme d'Anastase (le Sinaïte)', Oriens Christianus 3 (1903), 56-79; S. Heid, 'Die C-Reihe erbaulicher Erzählungen des Anastasios vom Sinai im Codex Vaticanus Graecus 2592', Orientalia Christiana Periodica 74 (2008), 71-114. 
comments about heroes of his stories (e.g. 'Christ-hater' and 'defiled'; AN, ch. 5.1 and ch. 9.6) and offers some explanations and clarifications. ${ }^{28}$ However, none of these omnipresent storytellers becomes as intimate and coherent as the storytellers in miracle collections. The storyteller's elliptical profile is most graphically illustrated in Daniel's text, where he as the omnipresent storyteller appears abruptly without any introduction. As teachers, all three storytellers are closer to the chain storyteller than to the single one. Their wisdom emerges through their role as successors in a chain. Likewise, these storytellers' voices acquire authority as an addition to previous or later storytellers' voices.

Benjamin's atemporality of experience in the three texts in question, as is the case with the chain analysed in the previous section, is manifested in the form of a blending of storytelling voices. An illustrative example can be found in the $S M$ when a group of monks, including Moschos himself, visit Savvas' monastery (ch. 3). The main storyteller reports that Athanasios, an elderly man tells him that when he (Athanasios) was at the monastery of Penthouklas, the presbyter Konon experienced a temptation about which our second storyteller, the elderly man, hears while he is at Konon's monastery. This constant shifting of voices is complemented by an equal shifting of geographical settings.

Interestingly enough, and as an addition to the constant voice shifting, in this collection the tales conclude, as a rule, without any indication as to who is the speaker until the end of the tale. To make this subtle point clear, we cite two examples. The first is the aforementioned episode involving Athanasios as a second storyteller, which concludes in the following manner: 'For twelve years he anointed and baptized ...; so he drew his life to a close' (SM, ch. 3, 2856). ${ }^{29}$ One could once again observe in this passage a blending of voices. In particular, since the tale has been put into direct speech, one could assume that the one who is speaking up to this point is Athanasios who tells the tale that Konon has told him, which reaches us through the voice of the main storyteller. Nevertheless, in the passage quoted above, which comes right after the tale's conclusion, we are not certain if Athanasios is the one still speaking or whether these words belong to the main storyteller.

One can also observe a blending of temporal frames. Once it is unclear who is the speaker, it also becomes unclear what is the temporal frame. It is not clear in the present instance whether we are at the point at which Athanasios tells the tale to the omnipresent storyteller or instead the point at which the omnipresent storyteller tells the tale to someone else. In fact, one comes across many tales in the SM which begin without introducing their new storyteller; he appears abruptly at some later point for us to realize that he has been the person speaking from the outset. Moreover, many times in the $S M$, the ending of a tale is left completely devoid of any discernible sense

28 In the first tale, for instance, he explains why he has associated the Saracens with the demons: 'for demons call the Saracens their friends and this is fair' (Anastasios' Narrations, ch. 1, 11-12).

29 Wortley, John Moschos, 6. 
of who is the speaker. A number of questions are left unanswered, such as whether the storyteller of the preceding chapter is the one who continues talking in the following chapter. At the same time, one wonders whether there is a switch back to the main storyteller who undertakes to tell a new tale.

Another illustrative example of the blending of narrative voices and temporal frames comes from DN. At some point, the omnipresent storyteller reports that at a certain unspecified time, Daniel insisted that he and the disciple accompanying him would stay in the street, since they had nowhere else to stay. This insistence causes the disciple's heated reaction. However, it seems that staying in the street eventually constitutes the springboard that allows Daniel to assume the role of storyteller. Suddenly an elderly man named Eulogios appears, who approaches and kisses Daniel's feet, inviting him to his house, along with his disciple and all the homeless he can find on the street $(D N$, ch. $6,15-21)$. On their way back to Skete, Daniel's disciple insists on being told Eulogios' story: who is this man and how does he know Daniel? Daniel refuses to satisfy the curiosity of his disciple, who once again is angered and refuses to provide Daniel board for the night (DN, ch. 6, 31-41).

If one considers that the meeting with Eulogios is the first incident that the omnipresent storyteller narrates, then Eulogios' story begins in medias res through the voice of the omnipresent storyteller and proceeds in the same manner until Daniel and his disciple leave Eulogios' house. What the disciple, and along with him the reader or external listener of the tale, desires to hear from that point on is the beginning of Eulogios' story, which Daniel has the privilege of knowing and is thus deemed responsible for sharing. Nevertheless, Daniel does not want to tell the story unless he receives his dinner $(D N$, ch. 6, 31-41). The occasion for the retrospective reconstruction of the story on behalf of the disciple (and the audience) is thus extended with a discussion concerning Daniel's denial, the disciple's insistence, and the food that has to be offered as a counter-gift to Daniel's act of storytelling. Under these conditions, the suspense as to the reason behind Daniel's behaviour is heightened. What is more, in contrast to his other tales, Daniel requests his disciple not to retell this particular story to anyone else $(D N$, ch. 6,56$) .{ }^{30}$ Thence, the audience of the collection is in a way initiated into the storyteller's secret. In brief, Daniel's narration concerns his own involvement in the way in which Eulogios' life evolves: the latter was living a life of philanthropy until Daniel guaranteed his salvation and everything changed. Eulogios gave up his God-loving life for a life of fame and wealth as a dignitary in Constantinople. After Daniel's repeated requests to God, Eulogios returns to his pious mode of living.

But even within Daniel's narration, we often lose track of who the storyteller is when the third-person singular is employed as a form of narration. The third-person singular is the omnipresent storyteller's grammatical person of preference throughout the collection. In fact, in the collection the first-person singular, when it is employed, refers to Daniel or 
other storytellers that form a chain, but never to the omnipresent storyteller who exclusively uses the third-person singular as a narrative mode. This feeling of confusion is intensified as the passing from Daniel's address to the protagonist, Eulogios (located in the past), to the narrative moment in which Daniel actually takes up the role of the storyteller for his disciple (located in the present) is not at all clear.

While Daniel narrates a past conversation with Eulogios, he suddenly switches to the present, addressing his disciple without any clear indication. The confusion of temporal frames becomes even more apparent when immediately after we switch to the omnipresent storyteller and to another time frame (the time of the composition or the time of each retelling of the tale):

This is what Abba Daniel confided to his disciple when they had returned from the Thebaid. Wondrous is the goodness of God, how in a short time he raised up Eulogios and again so humbled him to his benefit. Therefore we pray that we, too, may be humbled in Christ. ${ }^{31}$ (DN, ch. 6, 230-4)

Interestingly, this is the only time in the collection that the omnipresent storyteller employs the first-person plural. Additionally, within Daniel's narration there are other narrations of parts of the same story to persons other than the disciple, which are transmitted again through Daniel's voice. For example, Daniel narrates his intercessions for Eulogios' soul and the events leading to the two men's meeting, but without repeating the tale. Hence another time frame is added, the telling of the tale to Eulogios before it comes to be shared with the disciple.

Anastasios' collection presents a rather different manner of the blending of narrative voices. It begins by giving the impression that there is only a single omnipresent storyteller: Anastasios. It is only after six chapters have elapsed that the storytelling chain moves into the present. In order to understand why this would make a strong impression on the recipient, it is worth commenting briefly on the way in which the main storyteller is inserted each time from the first to the seventh chapter. The tale of the first chapter begins without having Anastasios identify himself: we are introduced to the story's protagonist instead $(A N$, ch. 1, 1). Then, Anastasios embarks on a comparison between demons and Saracens, which serves as the launching board that propels the narration of his second tale in the next chapter. In fact, the whole second chapter works as a justification as to why Saracens are even worse than demons.

The next chapter begins with a sudden recollection. The storyteller remembers that before the events of the previous tale had taken place, something similar happened to him while he was residing on the Mount of Olives $(A N$, ch. 3,1$)$. In the fourth chapter, the main storyteller decides to add to the story related in the second chapter, which provoked the narration of the third chapter, the reason for which he commits these stories to writing. His intention is to strengthen Christian faith. The tale that follows this statement constitutes an example of what can be achieved through faith $(A N$, ch. 4 , 
10-11). The fifth chapter begins with the introduction of the story's protagonist, while in the next one the storyteller establishes a geographical link with the previous chapter as he remembers that something else has happened at the same location.

From this brief exposition, we might draw the conclusion that the sequence of the tales is ordered according to the storyteller's memories and thoughts. He begins a tale by inserting its protagonist. A comment or a location in the story draws his thoughts elsewhere and this new direction determines the content of the next tale. At first glance, the seventh chapter seems to follow the same pattern, as it begins by establishing a temporal link with the previous stories $(A N$, ch. $7,1-3)$. Having already heard or read the stories of the previous six chapters, the audience is bound to believe that storytelling will continue through the main storyteller's voice. However, this impression changes when in the sixth line the plural pronoun 'us' occurs, implying that the tale is told by some 'true servants of Christ' through which a chain of storytellers is established. What has been hinted at in the above exposition, namely that the collection presents itself as straightforward with the storyteller's voice being singular and omnipresent, but that then the audience is faced with a voice that cannot be easily pinned down to the omnipresent storyteller or other storyteller(s), is apparent in other chapters of Anastasios' collection.

The collection of Anastasios thus preserves the appearance of having an omnipresent storyteller who arranges his tales according to how his memory orders them, but in fact this pattern is (intentionally) turned upside down through the insertion of other storytellers who cancel the boundaries between each telling voice, blending in turn the way Anastasios' memory supposedly orders the tales (since we don't exactly know that it is him who speaks), and thus confusing the pattern the omnipresent storyteller lays out. In sum, there is a simultaneous fading away of clear indications of who is the speaker and when, as we pass from one tale to another and from one episode to another in the collections that come under the combined storytelling mode. At times it is even unclear who is the speaker within the framework of a given episode. The repetitive occurrence of this phenomenon points to an intentional narrative technique exploited in different ways, a further inquiry would need to clarify what exactly is achieved through the mixture of voices and time frames.

A plausible argument would be that the voice- and time-blending between tales and episodes serves the atemporal dimension of tale experience: we lose grip of the identification of who speaks and thus our focus is directed at what happens. In this manner, the tales are evacuated of their historicity and transubstantiated into atemporal experiences. The storyteller's voice becomes a vague voice of the tale not anchored in a specific historical context, a technique creating a teaching experience for various recipients across time and space. In other words, the recipient experiences what happens in an atemporal time frame and 'lives' the lesson directed to him, which he in turn can transmit in another unspecified time frame in the future by assuming himself the role of the storyteller, and thus becoming the new voice of the tale. The atemporality of experience is ultimately identified with a constant repetition of the voice of the tale. 


\section{Conclusions: theory, application, and re-evaluation}

In order to assess the usefulness of the storytelling network established here, let us briefly return to the theoretical framework presented at the outset. Returning first to Fludernik's dictum that tales should be seen as narrative forms in their own right, it would now be plausible to suggest that our investigation of the storyteller in the examined works supports this. In his various forms, the storyteller appears to be an inherent feature of the hagiographical tale. A literary genre is traditionally considered to be a form of writing which presents governing principles repeated in every 'representative product' of the category. ${ }^{32}$ In this, the storyteller seems to be a principle repeated in all tales. On the other side of the coin, however, Fludernik's argument seems incomplete, at least as far as the Byzantine tale is concerned. The storyteller emerging from this corpus, is not a monolithic concept, but changes according to generic conventions and authorial intentions.

As regards Benjamin's approach to the storyteller, several points could be made. The storyteller's profile seems to be constructed in terms of Benjamin's elaborations. However, as far as early hagiographical tales are concerned, the manner in which experiences pass from mouth to mouth is not the same for every tale, and the storytelling modes and types established here are illuminating on this point. In the case of the single omnipresent storyteller, the source of the tale may or may not be indicated, but it never takes the form of another person who speaks. As for the chain of storytellers, the source is another storyteller whose source is another storyteller who retells what he has heard from a previous storyteller, and all of them are present in the text, even when their voices are mingled. In combined storytelling, both possibilities might be detected: the single voice of the omnipresent storyteller and the mingling of different storytellers' voices.

The same is valid with regard to the storyteller who becomes a teacher. In the case of the single storyteller, the teacher gives counsel based on the details he provides through which his story becomes truthful. In the case of chain storytelling, each storyteller assumes value because of the status of the previous storytellers forming the chain, who are all pious men with something beneficial to tell or to do. The combined storyteller, once again, applies features from both.

As regards the temporal experience suggested by Benjamin, the validity of this feature seems to be linked to the subgenre and storyteller in question since, as has been shown, it is manifested as the dominance of the voice when it comes to the single omnipresent storyteller and as the fading of the voice in the case of the combined storyteller. In sum, it seems that the concept of the storyteller is much more than meets the eye. As an inherent feature of Byzantine tales, he acquires many functions which

32 Such reflections on genre are provided in I. Nilsson, "Archaists and innovators: Byzantine "classicism" and experimentation with genre in the twelfth century', in B. Agrell and I. Nilsson (eds) Genrer och genreproblem: teoretiska och historiska perspektiv / Genres and Their Problems: theoretical and historical perspectives (Gothenburg 2002), 413-25. 
prove that it is a device being very carefully invested with authority, so as to carry out the desired outcome. The fact that there are different types of storytellers, each linked to a specific type of hagiographical collection, points to the fact that there is yet much more to know about the way the genre of the tale could assist in unravelling and, eventually, defining the multidimensional figure of the storyteller.

Stavroula Constantinou is Director of the Centre for Medieval Arts \& Rituals (CeMAR), University of Cyprus. She is Associate Professor of Byzantine Studies and Principal Investigator for three international projects funded by the European Commission and the Cyprus Research and Innovation Foundation. These projects concern medieval arts and rituals; late antique and early Byzantine motherhood and breastfeeding; and the late antique and early Byzantine tale.

Andria Andreou is a Postdoctoral Researcher at CeMAR, engaged in the project on the early tale. She obtained $a B A$ and an MA in Byzantine literature from the University of Cyprus, before completing her MPhil in European Literature and Culture at Cambridge. A published version of her PhD thesis 'The Holy Double: Identity, Desire and Holiness in Byzantine Passions and Lives of Couples' is in preparation. 